\title{
OBITUARY
}

\author{
ELSIE ELIZABETH ESTERHUYSEN (1912-2006)
}

On Tuesday, 9th June 2006, some 200 persons gathered in the conference room at the Kirstenbosch Research Centre of the South African National Biodiversity Institute in the Kirstenbosch National Botanical Garden, Cape Town, to pay homage to and celebrate the life of the late Elsie Esterhuysen. The memorial gathering was hosted and conducted by her nephew, Allan Lighton and his wife, Megan (née Esterhuysen), and comprised three speeches of tribute from the botanical fraternity and one from the Mountain Club of South Africa on her mountaineering prowess, followed by refreshments, with many personal reminiscences among those attending. The following are the contributions from the three botanists outlining her life and work and paying tribute to her wonderful contributions to botany, with personal reminiscences and anecdotes.

\section{John Rourke}

'Today we are here to celebrate the life of a legend, for Elsie was a legend, certainly within the local botanical community (Figure 1). She was born 94 years ago in Observatory, Cape Town, on 11 April 1912. Elsie attended the Wynberg Girls High School and after matriculating, proceeded to the University of Cape Town where she graduated with an M.A. degree in botany in 1933, the subject of her thesis being the anatomy of the resurrection plant, Myrothamnus flabellifolius Welw. But anatomy and physiology held little attraction for herright from those early days it was clear that field work was to be her abiding interest. After a brief period of employment as a clerk in the Education Department, her chance came with the award of the Solly Scholarship at Kirstenbosch in 1935. There she made a detailed study of the fynbos regeneration after the felling of a 50 yearold plantation of Pinus pinaster at the northern end of the Kirstenbosch estate - a mere few hundred metres from where we are gathered this afternoon. The results of this study form the basis of the few research papers she ever published.

Elsie had long wanted to join Dr I.B. Pole Evans' Botanical Survey group in the Department of Agriculture, but the Pretoria bureaucrats turned her down merely because she was a woman. In those days the very prospect of a female doing botanical survey work in the remoter parts of the South African bush was unthinkable! One of her classmates at university, John Acocks, was accepted by Pole Evans and went on to produce his famous Veld Types of South Africa. With the Great Depression at its peak, jobs were hard to come by and so in 1936 Elsie gratefully accepted a position as assistant to the redoubtable Maria Wilman, Director of the McGregor Museum, Kimberley, who was then undertaking a survey of the flora of Griqualand West. Miss Wilman insisted that Elsie should learn to drive in order to reach the more distant parts of the survey area. All went well until one day Elsie stalled the car on a level crossing. Despite the fact that there was no belching locomotive thundering down the line towards her, this incident proved to be a life-altering experience for her. She never drove again! Instead she took to pedal power and the bicycle, perfecting her cycling technique on a variety of models over the years. Who will ever forget the spectacle of Elsie's
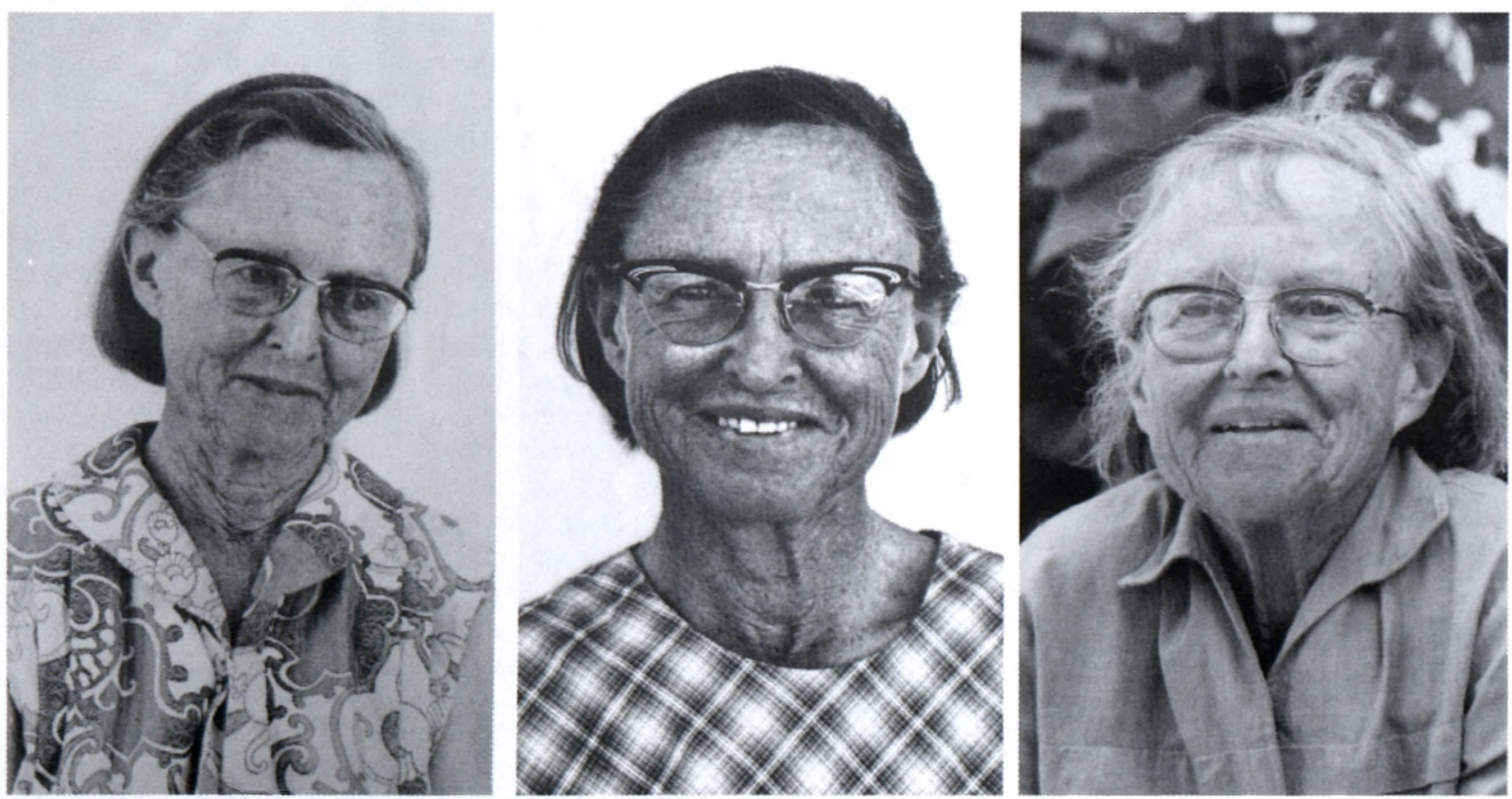

FIGURE 1A-C.-Elsie Esterhuysen (dates unknown; photographs courtesy of Bolus Herbarium). 
daily homeward journey from the Bolus Herbarium on her trusty bike, head forwards, hair streaming behind her, careering down the viciously steep Stanley Road at breakneck speed, then whipping into Lovers Walk, followed immediately by another swooping twist into Grotto Road-all with the panache of a Tour de France professional-before coming to a heart-stopping halt in Main Road, Rondebosch.

After two years in Kimberley, Elsie returned to Cape Town in 1938. It was here that her real career began when she joined the Bolus Herbarium (Figure 2) under another formidable woman, Dr Louisa Bolus. Her former professors, Robert Adamson and Harold Compton, knowing of her interest in mountaineering, suggested that she explore and document the high-altitude flora of the Cape Mountains as herbarium records from such areas were at that stage sparse or even lacking completely. This idea appealed immensely to Elsie and became the focus of her life's work for the next 60 years, during which time she amassed over 37000 herbarium collections. What makes this achievement even more remarkable is that having no transport of her own, she relied entirely on Mountain Club friends to provide lifts to the various sites she investigated, be they in the Western Cape mountains or the KwaZulu-Natal (KZN) Drakensberg.

It's an astonishing fact that for the first 18 years of her employment she received no proper salary and was

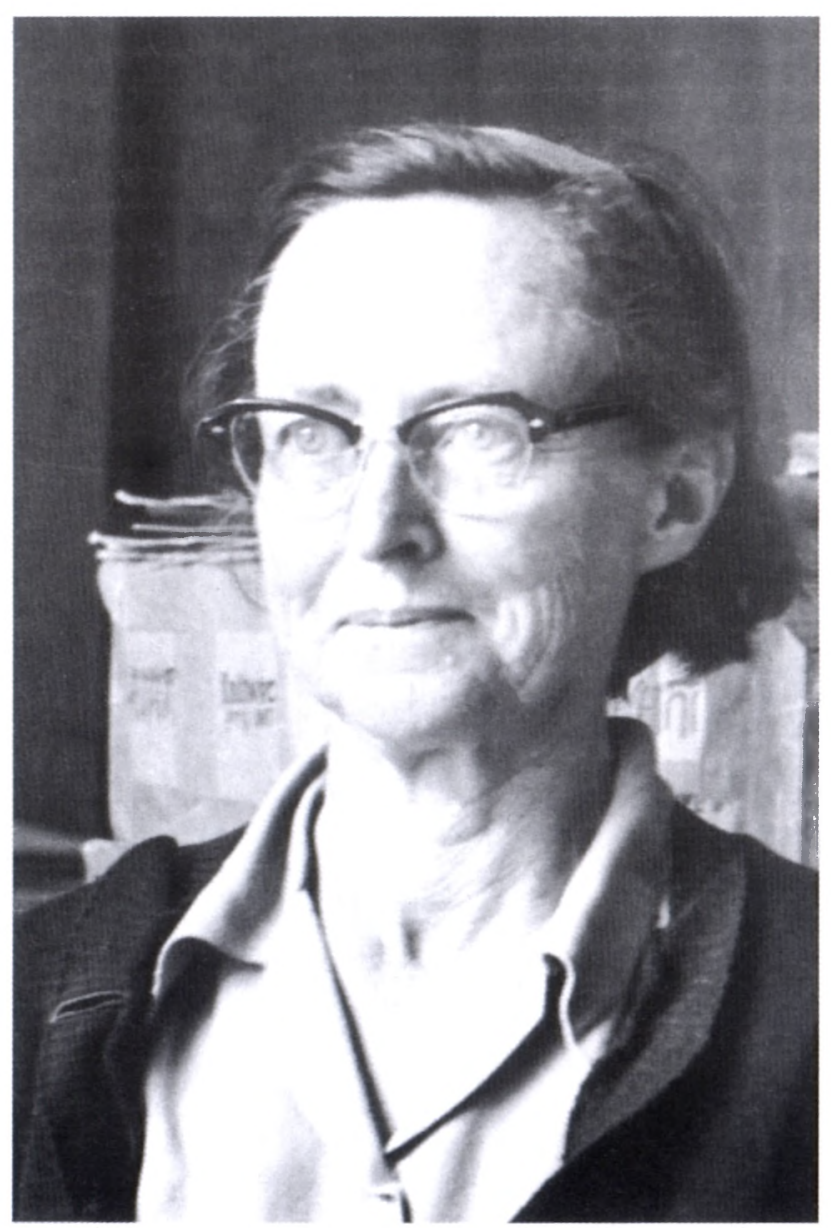

FIGURE 2.-Elsie Esterhuysen, taken in the Bolus Herbarium in 1962 (photograph by J.P. Jessop). paid out of petty cash at a rate not much better than a labourer. When Prof. Ted Schelpe arrived as curator of the Bolus Herbarium in 1956, he had to do battle with the bureaucrats in the University of Cape Town's administrative office to get a permanent establishment post created for her. It was the first time she had any financial security. Such was the extent of her loyalty and dedication.

She did not collect randomly; Elsie was above all an intelligent collector, seeking range extensions, local variants, or even new species, filling voids in the Bolus Herbarium's records, often returning months later to collect seeds or fruits that were of diagnostic importance. To do this effectively pre-supposed an encyclopedic knowledge of the published literature on the Cape flora and this she possessed to a remarkable degree. Despite being responsible for this avalanche of botanical discoveries, sustained over several decades, Elsie could not be persuaded to publish the results of her work under her own name. Instead she delighted in helping others; indeed Elsie seemed to take vicarious pleasure in seeing her own discoveries written up in a host of monographs by several generations of young taxonomists. Was it laziness, a fear of criticism or modesty that caused this curious reluctance to publish? Knowing Elsie, I feel sure it was her innate modesty. Always self deprecating, one of her favourite comments was 'I'm only filling in gaps'.

As postgraduate botany students at the University of Cape Town working in the Bolus Herbarium during the 1960s, many of us had the privilege of engaging in regular lunch-time discussions with her on a great many aspects of the Cape flora, while eating our sandwiches perched on the rather decrepit old sofa that graced the tearoom of the Bolus Herbarium. Though never part of the formal teaching staff, her influence was incalculable. But it was not only local botanists whom she helped. Eminent specialists from abroad all beat a path to her door to seek her expertise and assistance in the fieldfrom Switzerland, Sweden, Denmark, Germany and the USA, among others. It was a well-known fact internationally that if you were coming to South Africa to work on the taxonomy of any plant group in the Cape flora, the first person you had to see was Elsie Esterhuysen.

Although she published very little herself, the South African Association of Botanists recognized the huge contribution she had made in assisting others by awarding her their Senior Medal in 1987. Her old university also acknowledged her achievements. On the occasion of the University of Cape Town's conferment of an honorary Master of Science degree on Elsie in 1989 (Figure $3)$, the university orator referred to her as a 'botanical hunter gatherer'. The metaphor was very apt. Like a hunter gatherer, she was in perfect harmony with nature, never being wasteful, never taking more than was needed at the time, never defacing or contaminating the environment. She had a deep and profound respect for nature. It was almost like a religion to her.

Elsie was a person of huge warmth and generosity. She cared deeply for the oppressed, the downtrodden and the underdog. Tramps and vagrants who knocked at her door were often sent away in astonishment with a fist 


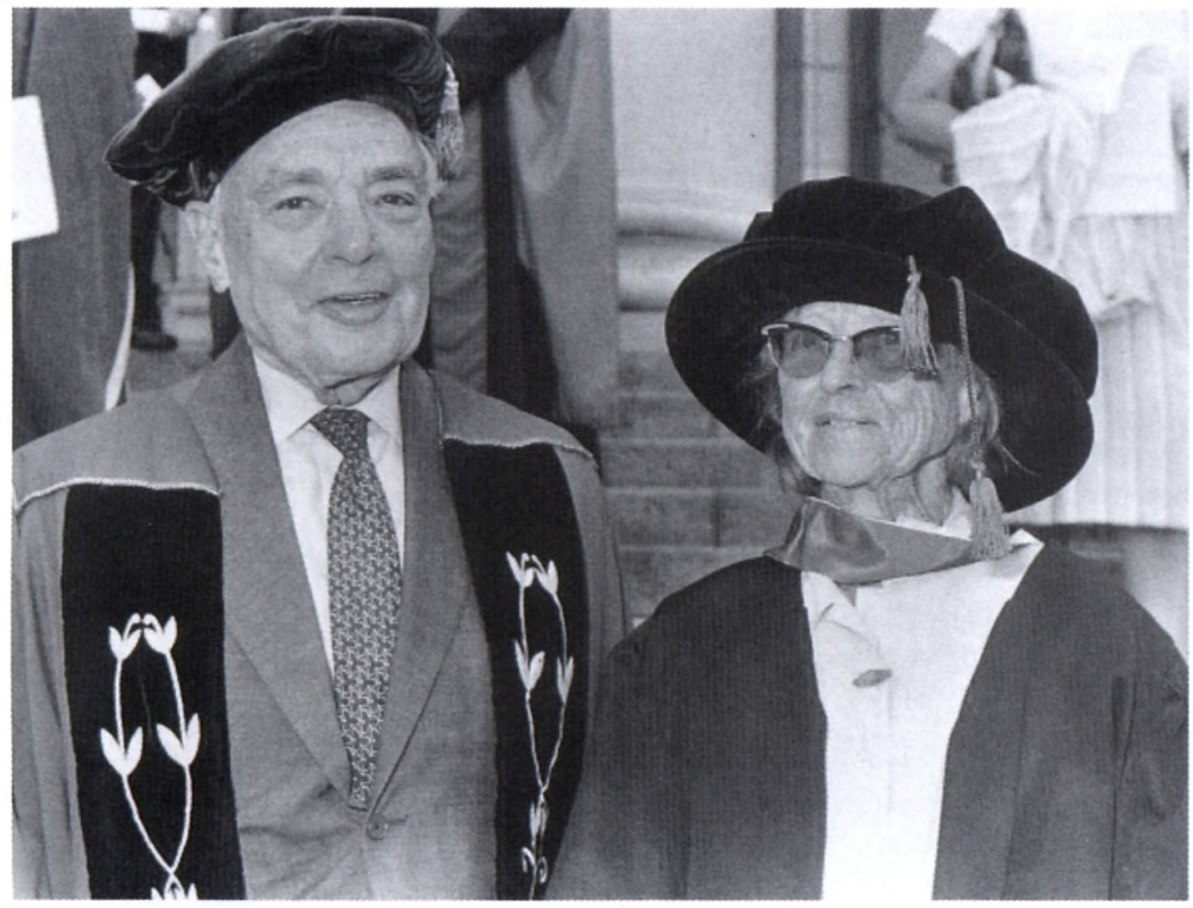

FIGURE 3.-Elsie Esterhuysen with the Chancellor of the University of Cape Town, Harry Oppenheimer, after her graduation in 1989 (photograph courtesy of Bolus Herbarium)

full of cash in their hands (but sadly, in her late eighties, she was attacked by one of them when he became greedy). We all know how frugal she was. Who else could survive for days in the mountains on half a raw cabbage, a few carrots, some powdered milk and weak tea? But on occasions she could let her hair down. I well remember offering to get her a drink at a book launch held at Kirstenbosch. A double brandy and ginger ale was requested and consumed with gusto! She was one of the most broad-minded and tolerant people I have ever met, yet there was one human folly of which she was extremely intolerant and that was smoking. Cigarette smoke was anathema to Elsie. How she coped with the chain-smoking of her boss I do not know. There was a memorable incident when an eminent but chain-smoking professor of biochemistry from Berlin ignored her pleas to desist from smoking on a field trip. Elsie calmly reached up, tore the cigarette from his lips, hurled it to the ground and crushed it underfoot! Needless to say, he did not light up again in her presence.

Today Elsie's botanical legacy lies within the folders of the Bolus Herbarium - a superb botanical archive, some of it already cited in major taxonomic publications by a host of local and international specialists. But many of her collections remain to be worked on like a huge untapped data base waiting to be sifted through and mined by future botanists in decades to come. And so Elsie's name will live on as later generations examine and dissect the specimens she gathered over a lifetime of prodigious activity. They will marvel at her achievements rather as we today marvel at the work of 18 th and 19th century explorers such as Thunberg and Burchell. Elsie was unique in the truest sense of that overworked word. We will not see her like again.'

Peter Linder, Zurich, Switzerland (read by E.G.H. Oliver)

'When I first started working in the Bolus Herbarium in 1973, as an undergraduate student wanting to know the names of the plants on the Piketberg, it was a curious place. There was a wonderful chaos of specimens, stacked on every available surface. On two floors was a superb library of the most magnificent books. Down in the tearoom was Ted Schelpe, twirling his moustache and smoking endless Mills cigarettes, a source of many ideas and inspiration. Tony Hall was in an office on the top floor, from where he organized a large number of conservation initiatives. Elsie was on the middle floor, and she was what I thought a botanist was supposed to be. She was in the mountains every weekend, and came back with big black plastic bags full of plants, that she sorted and passed to Gert Syster to press. She was the one person who could put names on plants that defeated my attempts. And she had little time for academic niceties-for her the important things were plants in the mountains, their welfare, their relationships. She was immersed in plants and mountains.

However, I only started to know her somewhat better when I worked on restios-although she knew the orchids, these were not a particular theme to her. But the restios had fascinated her since before the war. After Pillans had died (in 1964), she had taken on the mantle of the restio specialist. The really close collaboration only started after I had left for Kew as South African Botanical Liaison Officer-we had an intense correspondence about the species limits and the new generic limits I was proposing. When I left she had said that she does not write letters-well, I have a huge pile of her correspondence: detailed comments about each species, discussions about the best Latin for the diagnoses, discussions about the characters for the genera and the groupings that would be best to use. Her letters were a delight and a constant inspiration for me. She had built up a formidable knowledge about each species, knew its ranges, knew when it flowered. She would wait, sometimes for many years, until a mountain club trip took her back to where they occurred to collect seed, to extend the distribution ranges, to document the flowering times. Whereas Ted Schelpe taught me how to write descrip- 
tions and deal with nomenclature, Elsie taught me that each species has an essence, a character-that it liked some habitats but not others and that it flowered at a particular time. She was curious about the plants, not because they informed her about some theory or other, but she was interested in the plants themselves-she cared about them.

Elsie lived in a suburban house in Rondebosch, on a bleached and leached sandy soil. For many years she let most of the house, and lived in the servant's quarters. But the garden at the back was hers, and her cats'. It was full of remarkable bulbs that she had brought back from all over the Cape, and was delightfully overgrown. It was a pleasure to sit in the shade in the unmowed lawn, amongst a remarkable collection of species, drinking tea and talking about mountains and plants. Rumour had it that she also bathed in a tub in the back garden.

She also went to the mountains in the same way-not to climb them per se, but to be in them. She did not need clothing and equipment to keep nature out. She was simply at home in nature. The only natural element that she could not relax in was the sun.

The older of us probably all still remember Elsie in her working bay in the Bolus, immediately to the left on the first floor. She had a large table laden with specimens, comments on fading paper written in a fast, almost abbreviated handwriting, and tattered paper-covered revisions and books lying about. Under her table was a wooden footrest, in the tearoom her unusually low chair. She talked about her cats, and had a dry sense of humour. When Schelpe tested a prospective Ph.D. student by asking her what the differences between Selaginellaceae and Scrophulariaceae were, and then gleefully explained when the poor student did not know, Elsie remarked sotto voce that she, also, did not know what the difference was. Then there was the poor Austrian botanist that could not keep up with her in the mountains, when, after all, he came from the Alps. Or when I was rather nervous scrambling over an exposed cliff at the top of Ferny Gully and she said-well, you do have children to worry about.

I asked her once how she worked; my curiosity was aroused when I started a revision of Pentaschistis and found all specimens neatly identified in the herbarium, complete with the new species sorted out correctly at the end of the genus. She told me that she would collect all plants that she could not identify. This way she found genera in which the species taxonomy was inadequate. Then she would focus on a genus for several years, curating the old collections and attempting to name her new collections. When she found what she thought might be new species, she would start searching for more localities, in this way mapping the distribution ranges, flowering times, and ecology of each new species. By the time she was finished, the taxonomy was sorted out, the new species well documented, and all mounted and laid in the herbarium. In the case of the restios this even meant that there were little capsules with seeds, carefully collected in the field. It was left for the 'academics' to write the descriptions and the keys. This was the situation in Restionaceae and Pentaschistis, and
I would love to know whether it was also the situation in other genera, such as Agathosma and Phylica. And was she intrigued, or amused, by the antics of the academics? Or did she simply prefer fieldwork to writing, and fighting with reviewers?

She was, however, at times concerned about the recognition that she got for her work. She felt that the importance of her work was not always recognized by the University authorities. It was therefore really good that Hugh Amore took the initiative to convince the University to grant her an M.Sc. honoris causa. Hugh was at the time the Registrar of the University, a difficult and demanding task, he had enough to worry about. So much more to his honour, and to the fame of Elsie, that he took it upon himself to organize and co-ordinate this degree (see additions at end).

Several people had an important influence on Elsie. I do not know where her love for the plants came fromher origins were always a mystery to me. I never heard her talk Afrikaans, yet Esterhuysen is a good Afrikaans surname. Her focus on the montane plants was apparently started by a comment from Adamson, who wanted her to document the mountain summit floras. And the late interest in lowland floras I suspect came from Richard Cowling. Elsie once commented to me that she should have concentrated more on the lowland flora, as it was much more threatened than the montane flora.

And how many people did Elsie influence? That is hard to know. She had a subtle, but very powerful, influ-

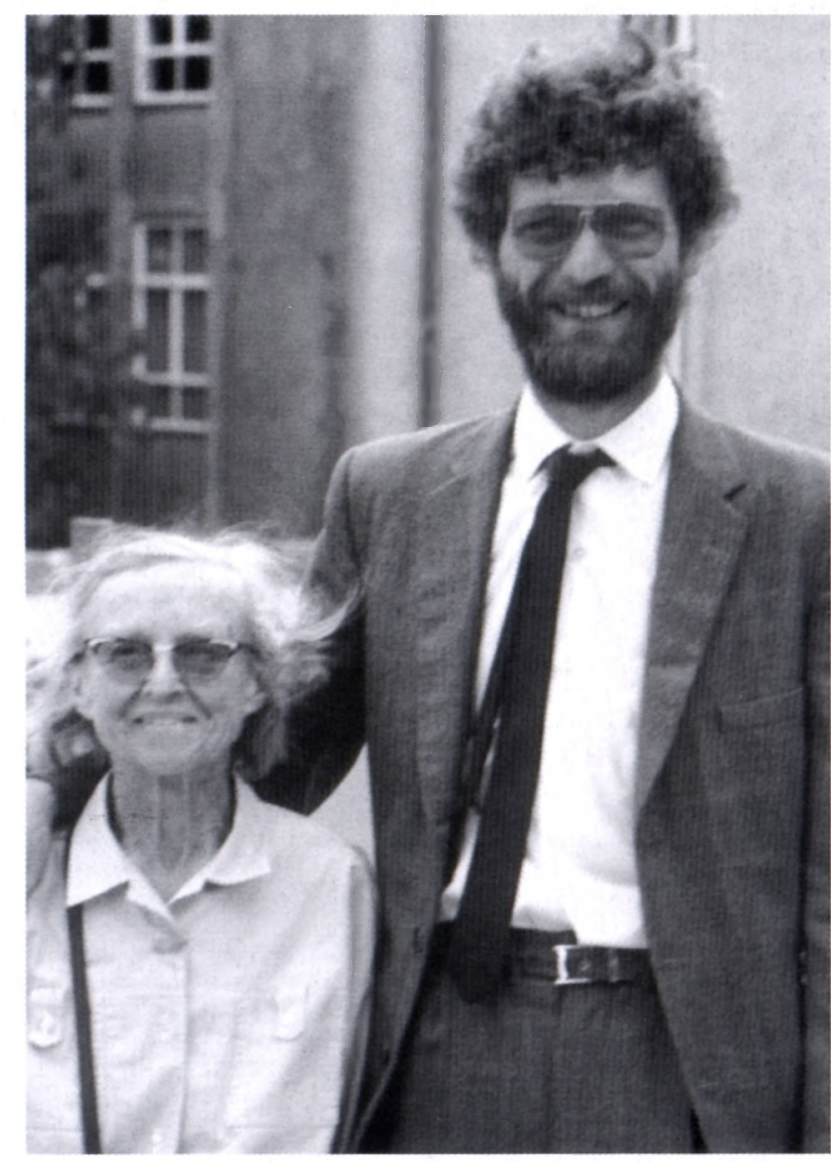

FIGURE 4.--Elsie Esterhuysen and Prof. Peter Linder after the graduation in 1989 (photograph G. Scott, courtesy of Bolus Herbarium). 
ence on me (Figure 4). And I suspect that many of her fellow mountaineers, and also many of the botanists that passed through the Bolus, were deeply affected by this tiny, remarkable woman, who was so much at one with nature.'

\section{Ted Oliver}

'We are here this afternoon for a very special purpose-to pay tribute to an extraordinary person who in some way, small or large, came into our lives. Death, memorial services, funerals are usually solemn occasions filled with sadness, sometimes tears. But don't let us go that route here. Let us rather celebrate a wonderful life that has finally come to an end. Yes, it is sad that we have lost Elsie, but then at 94 she did live well beyond her three score years and ten. In the end, through loss of memory, she was a burden unto herself and her death was indeed a happy release for her on 31 May 2006.

I first got to know Elsie in 1958, and like Peter, as an undergraduate wanting to know something about the Cape flora. At that time I also met her because she lived in a flat above a double garage along the road from my family home in Rondebosch (the house of Brian and Joan Quail of the Mountain Club). Just behind our house was a large residence for old people, The Abbotsleigh, where Elsie's mother had moved in. And so Elsie often came past our house to visit her mom.

In the Bolus Herbarium I was keen to learn about ericas which I had seen on our family holidays near Betty's Bay-who better than Elsie to help me. She had concentrated on Erica collecting at the insistence of Mrs Bolus who had helped her uncle Harry Bolus write them up for Flora capensis (1896-1905). She was very generous with her encouragement and guidance for this youngster who was now encroaching on her territory, but never once relayed any thoughts of this to me. Thanks very much Elsie.

The first of Elsie's few publications was the description of a new species, Erica viscidiflora in 1936, and then E. cremnophila in 1940 with Capt. Salter. Then came Dr Hans Dulfer, in Vienna, with his revision of Erica in the early 1960s. Elsie sent him a few batches of some of her problem material to show him some of the difficulties in the genus, whereupon he promptly thanked her, and described them all as new species. This put the wind up Elsie's sails and she decided to send no more material and promptly wrote a paper on her views on certain species just before his revision came out. This was her only major publication as sole author. Two things must have galled her (from the grunts one picked up)-Dulfer put the holotypes of her material in Vienna and he sank her E. viscidiflora! One felt from her veiled comments that this must have stifled any further ideas of publications. Little did she know that her viscidiflora is a good species that my late wife and I have reinstated. Later, of course, through Peter's research, she was encouraged to publish in his papers (Esterhuysen in Linder 1985, 1990) all her new species of Restionaceae that she had so assiduously been collecting over the years-some 47 species.

We have heard that Elsie concentrated her efforts on collecting, but not only in the Cape Florsitic Region (CFR), she did much in the KZN Drakensberg mainly on the annual July camps of the Mountain Club (Figure 5). One of her early mentors was Dr Henri Georges Fourcade with whom she worked and collected for his

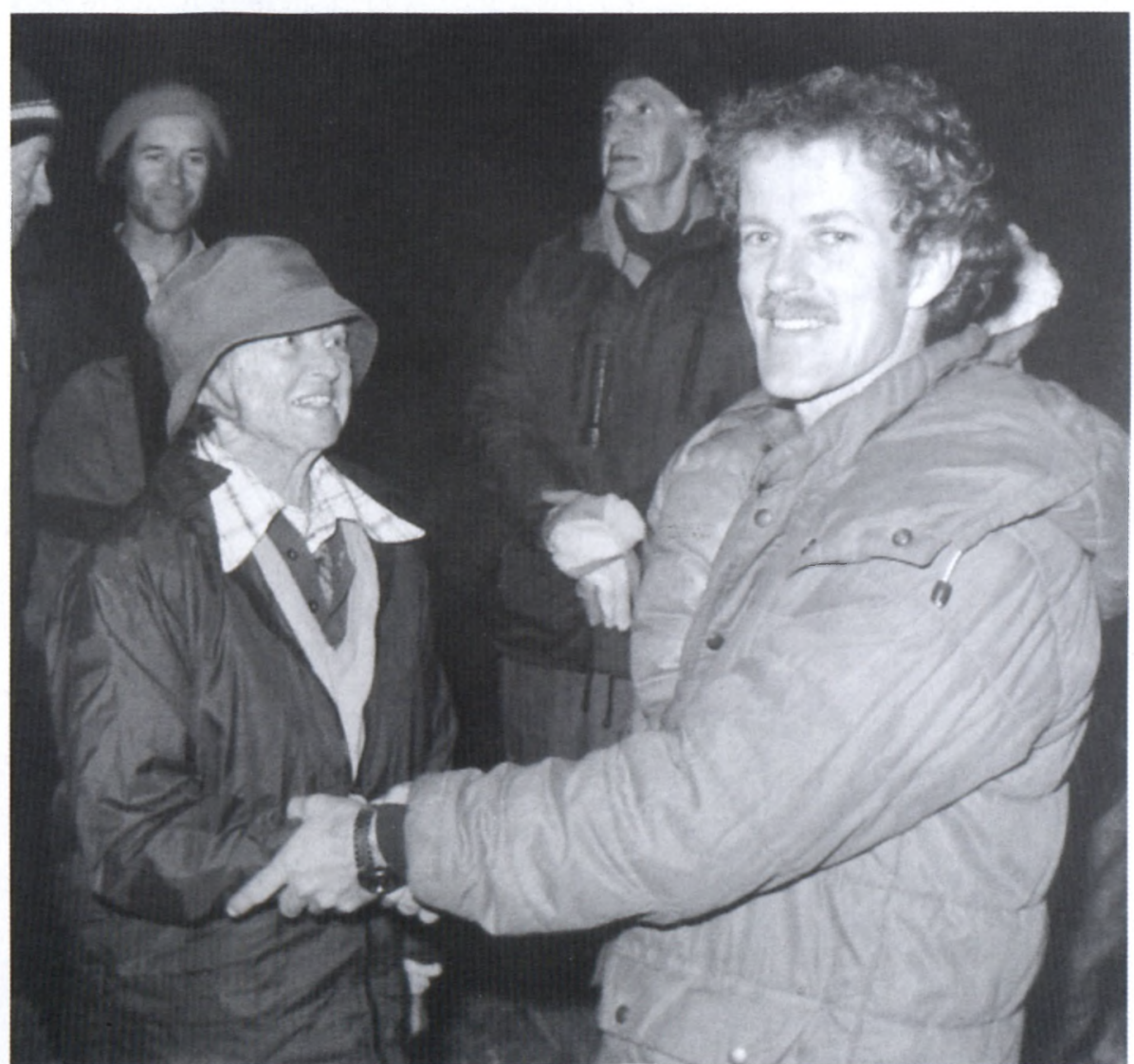

FIGURE 5.-Elsie Esterhuysen at the Mountain Club's Drakensberg July Camp of 1987 where she is being made 'a free woman' on receiving the Freedom of July Camps from the chairman of the local branch, Dr Graham Smith (photograph by B. Cooke). 


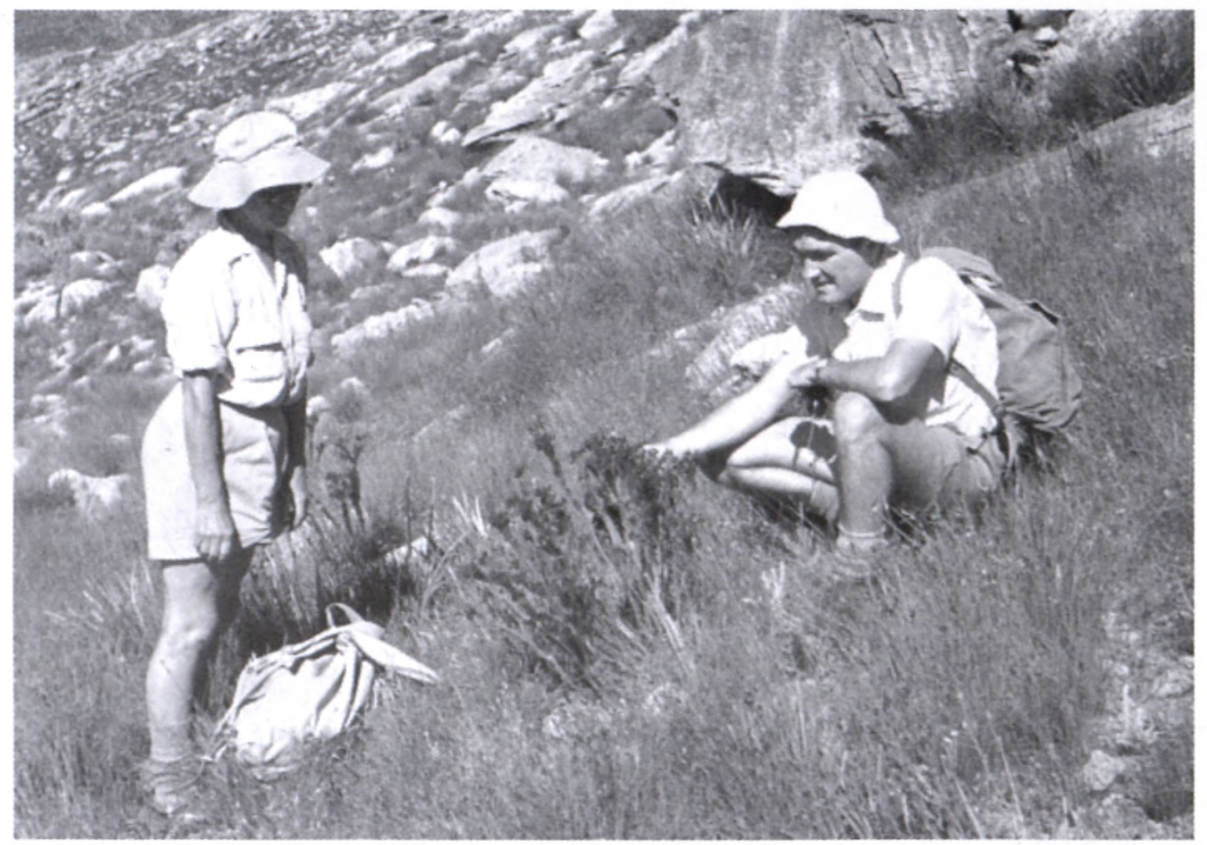

FIGURE 6.-Elsie Esterhuysen with Ted Oliver and the type plants of Erica atrovinosa in the Hex River Mtns in 1964; she discovered it in 1942 (photograph M.F. Thompson).

work on the flora of the Knysna/Uniondale area. As a collector she was certainly the most prolific for the CFR and ranks among the top three in South Africa with Compton and Acocks, all with just short of 40000 collections.

But how did she manage this? John has mentioned her lack of enthusiasm for cars, although she did once much later say that if Mrs Bolus in her late 80s still drove her tiny black Austin, perhaps she should take up driving again! So how did she get to all those remote places. The answer-the Mountain Club as John mentioned. Because the MCSA members did not roam around the flats, this is why I suspect she tackled them only later in life as Peter mentioned. She joined the club in 1935 !

But her mode of transport was the bicycle (we have her latest model here today). She rode to UCT up that dreadful steep road every day for a lifetime, come sunshine or rain, heat or cold. Now one knows why she was so fit and could outstrip any poor unsuspecting younger botanist in the mountains! Every day she would come up and park her bicycle behind the Bolus Herbarium building and then often jump through the window in the preparation section rather than walk all the way around to the front door. One day I happened to be looking out of the window and saw Elsie leaping onto her bicycle to go home, and lo and behold, a bit further down the University Ave between the Physics Dept and the Science Lecture Theatre, she actually fell off it in front of a group of students! The next day she told me she had never been so embarrassed.

Peter noted her quiet presence in the corner of the tearoom on that extraordinarily low chair. There she would sit with her oversized enamelled mug full to the brim with skimmed milk and a touch of tea. One hardly saw her with anything else, perhaps an orange or an apple, even on trips into the mountains. It is amazing how she managed to climb so many mountains and live so long on powdered skim milk. But she did have one serious health problem-her very thin skin which was always getting scratched and infected in older life.

Conversation at tea time was very varied with only the occasional comment from Elsie who spent most of the time endlessly stirring and sipping her milky tea. But things changed for her when something political was mentioned (yes Elsie was quite a liberal) or if someone mentioned the word CAT. Elsie loved her cats-sometimes too much. She was known to buy choice meat for the cats rather than herself; and to give up her bed and sleep on the floor rather than disturb the sleeping cats on her bed at bedtime!

I had wonderful trips with Elsie in those early days (Figures 6, 7) and later in the 1980s with Dolf Schumann-Hex River Mountains, Kogelberg and Swartberg. She always slept apart from us, never on a mattress, preferring to make a nice nest out of restios and slangbos, or, in the Drakensberg, lots of grass (Figure 8). Peter

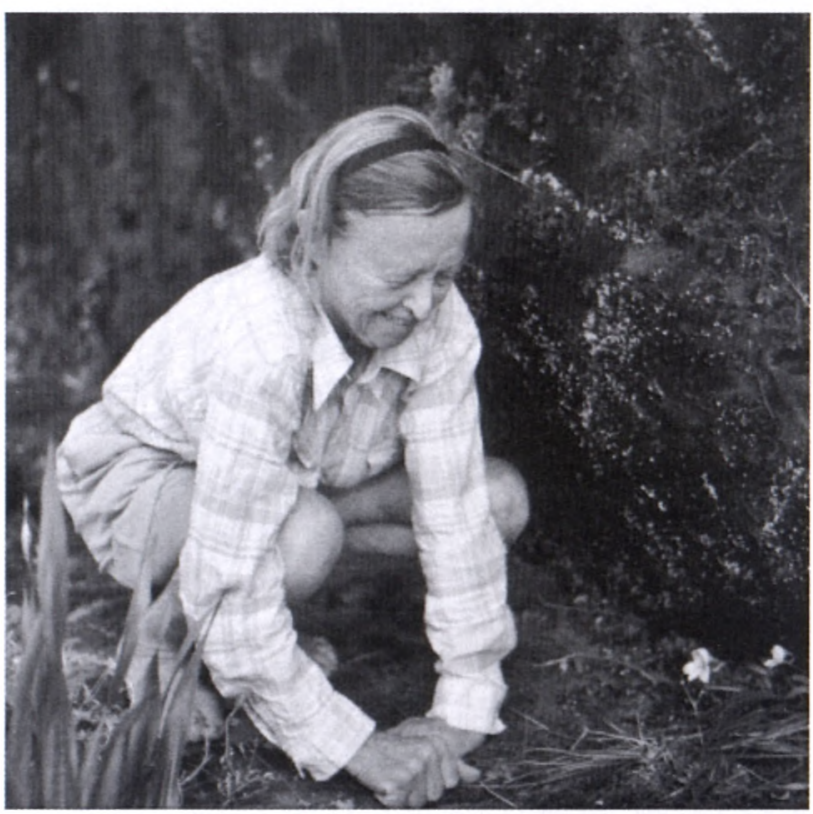

FIGURE 7.-Elsie Esterhuysen with the orchid, Disa longicornu, on Table Mountain (date unknown, photograph by M. Burger). 


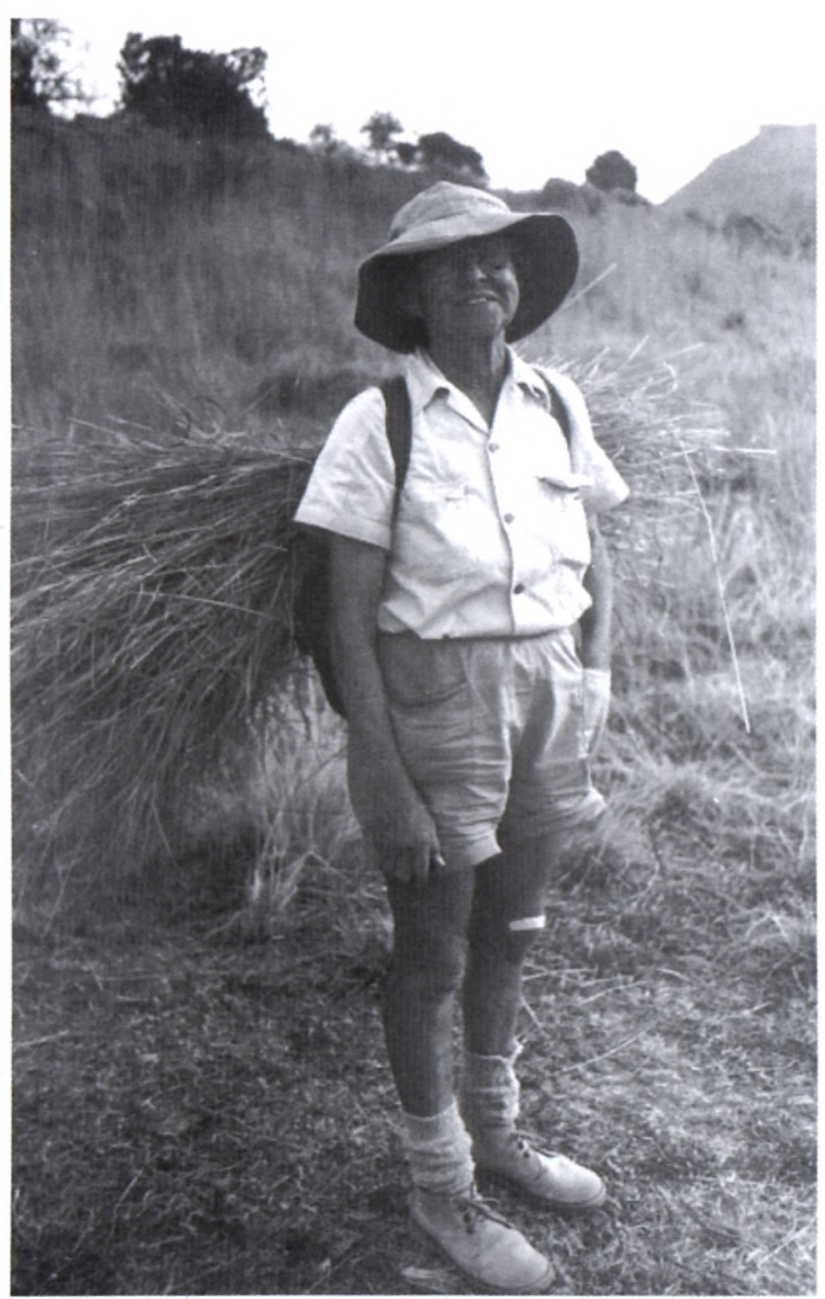

FIGURE 8.-Elsie Esterhuysen in the Drakensberg with a load of grass bedding for the night in July 1982 (photograph courtesy of Bolus Herbarium

has alluded to her behaviour in nature-with mumbled apologies she was not averse to shedding everything and hopping into a little stream to cool off! One of her greatest experiences was coming along with Dolf Schumann and myself in 1990 from Cape Town on a helicopter trip which Dolf organized to photograph the rare Erica alfredii in the Riviersonderend Mountains. On the return flight I persuaded the pilot to go low along a very devious route through the mountains via Jonaskop, Kaaimansgat, Goudini Sneeukop and Victoria Peak. She was amazed at seeing from the air all those mountains that she knew personally on the ground.

I shall cherish the moments I had with Elsie in the herbarium and in the mountains, I am only sorry that I was away from the Bolus working at Kew, Pretoria and Stellenbosch. Elsie was not a religious person but she must definitely have communed with God and nature in her own way in her countless days and nights in the mountains.

Let us give thanks for Elsie's life-for her great contribution to the study of our unique flora, through her superb collections that will last for as long as man continues to study plants from the Cape, and, hopefully, maintain herbaria. She will be remembered in two genera and about 56 species with Erica having three of them (Table 1).
When any of you next go up into the mountains, know that Elsie's spirit will be around somewhere in her paradise. Perhaps you will feel her presence in those large restiad clumps.

Thank you Elsie-you were a great person, mentor and friend.'

\section{Note added in the preparation of this obituary}

Elsie's parents were Johannes Petrus le Roux Esterhuysen (Afrikaans speaking) and her mother, Florence Ethel Larkin (English speaking)-hence her mother tongue. Her father attended Victoria College, Stellenbosch, where he studied law and then worked in the master's office of the Supreme Court in Cape Town. He was transferred from Cape Town to Windhoek where Elsie visited her parents by train during holidays. He retired early due to Florence not liking the Windhoek climate, and bought a smallholding at De Hoek, outside Joubertina in the southern Cape, where his son, Cyril, was the local attorney. Elsie visited the family there during her early botanical years at the Bolus Herbarium, hence her contact and friendship with Dr Fourcade who lived across the Tzitzikama Mountains at Witelsbosch

A newspaper cutting found among her personal effects after her death showed a side of Elsie that none of us knew existed. It was from the local Kimberley newspaper (undated) and reported on a Reading on life and works of Franz Schubert at a meeting of the Kimberley Philharmonic Society. The lecture was given by Miss E. Esterhuysen. It was preceded by another describing Burchell's travels in South Africa during Schubert's time and was followed by 'a delightful short programme of the composer's music played as piano solos by Miss Esterhuysen'.

Elsie was also an accomplished artist as evidenced by the few charming watercolours of flowers that were among her effects. She illustrated with black and white line drawings the species of Erica which she described with Salter.

Elsie celebrated her 80 th birthday by climbing the $2000 \mathrm{~m}$ high Sneeuberg in the Cederberg Wilderness area with friends from the Mountain Club.

Also in her effects was a handwritten letter to the principal of the university about her honorary degree and this shows something of her character:

\section{'Dear Prof Saunders}

Thank you for your kind letter of 9th Jan. I accept the award of the honorary degree and appreciate the honour.

I wonder, though, whether the staff of the Botany Dept were consulted. If the matter were not confidential I should like to consult them myself because it does not seem to me that my work warrants the hon. degree. I hope Council were not misled into supposing that the discovery of undescribed species was a great achievement because it wasn't. Apart from that I worked as a technician keeping the herbarium in order and up to date.

\section{Yours sincerely}

Elsie Esterhuysen' 
TABLE 1.-Plants named after Elsie Esterhuysen. Accepted names in roman type and synonyms in italics

Direct names
Bryophyta
Lophocolea esterhuysenii(ae) S.W.Arnell (1963) [= L. bewsii (Sim)
$\quad$ Grolle $]$
$\begin{aligned} & \text { Plagiochila esterhuysenii(ae) S.W.Arnell (1963) [= P. squamulosa Mitt. } \\ & \text { var. crispulo-caudata (Gottsche) Vander Berghen }]\end{aligned}$
Pteridophyta
$\begin{aligned} & \text { Dryopteris esterhuyseniae Schelpe \& N.C.Anthony (1982) [= Dryopteris } \\ & \text { dracomontana Schelpe \& N.C.Anthony }]\end{aligned}$

Apiaceae

Chamarea esterhuyseniae B.L.Burtt (1991)

Asphodelaceae

Bulbine esterhuyseniae Baijnath (1987)

Trachyandra esterhuysenae Oberm. (1962)

Asteraceae

Anderbergia elsiae B.Nord. (1996)

Athanasia elsiae Källersjö (1991)

Chrysocoma esterhuyseniae Ehr.Bayer (1981)

Corymbium elsiae Weitz (1989)

Felicia esterhuyseniae Grau (1973)

Hydroidea elsiae (Hilliard) P.O.Karis (1990) [三 Atrichantha elsiae Hilliard (1981)]

Troglophyton elsiae Hilliard (1983)

Brassicaceae

Heliophila esterhuyseniae Marais (1966)

Bruniaceae

Lonchostoma esterhuyseniae Strid (1968)

Tittmannia esterhuyseniae Powrie (1969)

Chenopodiaceae

Salsola esterhuyseniae Botsch. (1973)

Cyperaceae

Ficinia esterhuyseniae Muasya (2005)

Droseraceae

Drosera esterhuyseniae (T.M.Salter) P.Debbert (1992) [ D D. curviscapa T.M.Salter var. esterhuyseniae T.M.Salter (1939)], [D. aliciae Raym.-Hamet]

\section{Ericaceae}

Erica

elsieana (E.G.H.Oliv.) E.G.H.Oliv. (1987) [三 Philippia elsieana E.G.H.Oliv. (1984)]

esterhuyseniae Compton (1941)

esteriana E.G.H. Oliv. (1987) [三 Philippia esterhuyseniae E.G.H.Oliv. (1984)]

Fabaceae

Amphithalea esterhuyseniae (Granby) A.L.Schutte (1998) [三 Coelidium esterhuyseniae R.Granby (1980)]

Aspalathus esterhuyseniae R.Dahlgren (1960)

Lotononis esterhuyseniana B-E.van Wyk (1990)

Hyacinthaceae

Elsiea F.M.Leight. (1944) see Bothalia 12: 323 [= Ornithogalum paludosum Baker (1874)]

Lachenalia esterhuyseniae W.F.Barker (1978)

Ornithogalum esterhuyseniae Oberm. (1978)

Iridaceae

Geissorhiza

elsiae Goldblatt (1985)

esterhuyseniae Goldblatt (1985)

Hesperantha elsiae Goldblatt (1984)

Ixia esterhuyseniae M.P.de Vos (1988)

Moraea elsiae Goldblatt (1976)

Romulea atrandra G.J.Lewis var. esterhuyseniae M.P.de Vos (1972)

Watsonia elsiae Goldblatt (1989)
Linaceae

Linum esterhuyseniae C.M.Rogers (1982)

Lobeliaceae

Lobelia esterhuyseniae E.Wimm. (1968) [= L. comptonii E.Wimm (1968)]

Mesembryanthemaceae

Aridaria esterhuyseniae L.Bolus (1939) $[=$ A. noctiflora (L.) Schwantes var. straminea (Haw.) Gerbaulet (1996)]

Delosperma esterhuyseniae L.Bolus (1959)

Erepsia esterhuyseniae L.Bolus (1939)

Esterhuysenia L.Bolus (1967)

Gibbaeum esterhuyseniae L.Bolus (1958)

Lampranthus esterhuyseniae L.Bolus (1958)

Ruschia esterhuyseniae L. Bolus (1950)

Orchidaceae

Disa esterhuyseniae Schelpe ex H.P.Linder (1981)

Polygalaceae

Muraltia

elsieae Paiva (1981)

esterhuyseniae Levyns (1949), in obs., sine descr. lat. (IK)

Proteaceae

Paranomus esterhuyseniae Levyns (1970)

Restionaceae

Askidiosperma esterhuyseniae (Pillans) H.P.Linder (1985) [三 Chondropetalum esterhuyseniae Pillans (1945)]

Calopsis esterhuyseniae (Pillans) H.P.Linder (1985) [” Leptocarpus esterhuyseniae Pillans (1945)]

Elegia esterhuyseniae Pillans (1945)

Ischyrolepis esterhuyseniae (Pillans) H.P.Linder (1985) $[\equiv$ Restio esterhuyseniae Pillans (1945)]

Ceratocaryum fimbriatum (Kunth) H.PLinder [= Willdenowia esterhuyseniae Pillans (1945)]

Rosaceae

Cliffortia esterhuyseniae Weim. (1948)

Rubiaceae

Anthospermum esterhuysenianum P.uff (1986)

Rutaceae

Agathosma esterhuyseniae Pillans (1950)

Euchaetis

elsieae 1. Williams (1979)

esterhuyseniae I.Williams (1979)

Scrophulariaceae

Diascia esterhuyseniae K.E.Steiner (1999)

Selago

elsiae Hilliard (1999)

esterhuyseniae Hilliard (1998)

Trieenea elsiae Hilliard (1989)

Thymelaeaceae

Passerina esterhuyseniae Bredenk. \& A.E.van Wyk (2003)

\section{Names in allusion}

Asteraceae

Monticapra (Karis) Koekemoer (2001). [ = Disparago section Monticapra Karis (1993)]: mons, montis, a mountain, and capra, a she-goat; hence like a mountain she-goat (see below)

Ericaceae

Erica oreotragus E.G.H.Oliv. \& I.M.Oliv. (2001) [三E. esterhuyseniae Compton var. trimera Compton (1941)]: Oreotragus oreotragus, the klipspringer antelope; referring to Elsie's adept way of hopping around the mountains like a free klipspringer in search of choice plants! (see above)

Scrophulariaceae

Trieenea Hilliard (1989): Tri-eenea, three e's for E.E. Esterhuysen (Trieenea elsiae). 


\section{PUBLICATIONS BY ELSIE ESTERHUYSEN}

ESTERHUYSEN, E.E. 1936a. Plantae novae africanae. Series VI Erica viscidiflora Esterhuysen. Journal of South African Botany 2: 63,64 .

- 1936b. Regeneration after clearing at Kirstenbosch. Journal of South African Botany 2: 177-185.

- 1943. Coleonema nubigenum Esterh. Journal of South African Botany 9: 137.

- 1950. Rutaceae: Coleonema, Diosma, Adenandra, Macrostylus \& Barosma. In R.S. Adamson \& T.M. Salter, Flora of the Cape Peninsula. Juta, Cape Town.

- 1963. Notes on South African species of Erica. Journal of South African Botany 29: 51-58.

- 1985. New species in Askidiosperma, Calopsis, Chondropetalum, Elegia, Hypodiscus, Ischyrolepis, Nevillea, Platycaulos, Restio, Staberoha and Thamnochortus. In H.P. Linder, Conspectus of the African species of Restionaceae. Bothalia 15: 396, 420, 421, $423,428,432,434,459-462,465,466,472,477,489$.

- 1990. New species in Anthochortus, Calopsis and Ischyrolepis. In H.P. Linder, New species of African Restionaceae. South African Journal of Botany 56: 454, 456.
ESTERHUYSEN, E.E. \& SALTER, T.M. 1940. Plantae novae africanae. Series XIII. Erica cremnophila Esterh. \& T.M.Salter. Journal of South African Botany 6: 1, 2.

- 1941. Plantae novae africanae. Series XVI. Erica calycina L. var longibracteata Esterh. \& T.M.Salter. Journal of South African Botany 7: 82, 83 .

- 1950. Erica calycina var. longebracteata Esterh. \& T.M.Salter. In R.S. Adamson \& T.M. Salter, Flora of the Cape Peninsula: 657. Juta, Cape Town.

\section{E.G.H. OLIVER* (Compiler), J.P. ROURKE** and H.P. LINDER***}

* Formerly: Compton Herbarium, South African National Biodiversity Institute. Present address: Dept of Botany \& Zoology, University of Stellenbosch, Private Bag X1, 7602 Matieland, South Africa. Email: eoliver@sun.ac.za.

** Compton Herbarium, South African National Biodiversity Institute, Private Bag X7, 7735 Cape Town.

*** Institute for Systematic Botany, University of Zurich, Switzerland. 